\title{
Creating a "Safe and Supportive Environment:" Mentoring and Professional Development for Recent Black Women Doctoral Graduates
}

\author{
Tamara Bertrand Jones and La'Tara Osborne-Lampkin \\ Florida State University, Tallahassee, FL, USA
}

tbertrand@fsu.edu losbornelampkin@fsu.edu

\section{Shawna Patterson University of Pennsylvania, Philadelphia, PA, USA}

shawnap@upenn.edu

\author{
Dannielle Joy Davis \\ St. Louis University, St. Louis, \\ MO, USA \\ didavis@slu.edu
}

\begin{abstract}
Formal structures that support doctoral student socialization are limited, while formal programs for Black women doctoral students specifically are even more scarce. The purpose of this research was to examine an early career professional development program for Black women doctoral students and its influence on the mentoring relationships developed by participants. We conducted individual interviews with six Black women who participated in the Research BootCamp ${ }^{\circledR}$, an early career professional development program, as doctoral students. Two salient features of the program were identified, including its structure and intentional focus on intersectionality. Our findings also indicate that early career professional development provided opportunities for participants to develop sustainable mentoring relationships. The formal structure of the Research BootCamp ${ }^{\circledR}$ facilitated Black women doctoral students in developing mentoring networks through continued engagement with senior scholars and peers, provided social support, created outlets for professional development, built research capacity, and contributed to Black women's overall socialization to the academy.
\end{abstract}

Keywords: doctoral student socialization, Black women, mentoring, professional development

\section{Introduction}

Underrepresented doctoral students need to feel a sense of belonging (Winkle-Wagner, Johnson,

Material published as part of this publication, either on-line or in print, is copyrighted by the Informing Science Institute. Permission to make digital or paper copy of part or all of these works for personal or classroom use is granted without fee provided that the copies are not made or distributed for profit or commercial advantage AND that copies 1) bear this notice in full and 2) give the full citation on the first page. It is permissible to abstract these works so long as credit is given. To copy in all other cases or to republish or to post on a server or to redistribute to lists requires specific permission and payment of a fee. Contact Publisher@InformingScience.org to request redistribution permission.
Morelon-Quainoo, \& Santiague, 2010). Institutions and departments signal this to students in many ways, one of which is through the support they receive. Young and Brooks (2008) suggest that support for underrepresented racial/ethnic doctoral students occurs in phases throughout the students' program, beginning with recruitment. The authors propose that effective support 
for underrepresented doctoral students involves attendance at national conferences; publication opportunities; internship experiences; and networking with practitioners and scholars, and other graduate students of color locally and nationally. While these activities may be effective, these mechanisms "suffer from a lack of sustainability or can be disconnected random acts of improvement rather than a coherent, integrated component of a strategic plan to support graduate students of color" (Young \& Brookes, 2008, p. 404). Young and Brooks found that informal supports were most effective when complemented by a comprehensive formal structure. Unfortunately, formal structures that support underrepresented racial/ethnic doctoral student socialization are limited.

Not all institutions or departments recognize the need for formal programs for doctoral students of color, resulting in a gap for doctoral students of color, and Black women in particular. Other institutions or departments that do recognize the inherent benefits of these support structures may simply lack the resources needed to create and sustain such efforts. In response to the gaps left by this unmet need for Black women doctoral students, Sisters of the Academy (SOTA) Institute developed the Research BootCamp ${ }^{\circledR}$, an early career professional development program designed to support Black women's socialization to academe, and contribute to their social support outside of their home institutions.

In other work, we proposed that socialization includes three components; academic preparation; mentoring; and professional development (Bertrand Jones \& Osborne-Lampkin, 2013; DavisMaye, Davis, \& Bertrand Jones, 2013). For doctoral students, coursework lays the foundation for research and creative scholarship, as well as a solid grounding in a professional context (Golde, 2010; Turner et al., 2012). Mentoring refers to formal and informal professional relationships between doctoral students, as well as early career and senior faculty (D. J. Davis, Reynolds, \& Bertrand Jones, 2011). Professional development typically includes formal and informal opportunities for professional growth. For the purposes of this study, we focus our attention on the mentoring functions of early career professional development.

Our research is grounded in understanding the ways that formal structures for socialization contribute to the development of graduate students for faculty positions and other professional careers in academia. In conducting interviews with doctoral students, we answer the following: What are the most salient features of the Research BootCamp ${ }^{\circledR}$, an early career professional development program for Black women? And, in what ways did participation in the Research BootCamp ${ }^{\circledR}$ influence participants' development of mentoring relationships?

Understanding the role of professional development and mentoring in the socialization of Black women doctoral students brings attention to ways that institutions can improve upon their development and retention initiatives for diverse populations. Moreover, further unpacking key elements embedded in components (e.g., mentoring and professional development) of the socialization process can provide insight for models, frameworks, and programs to support institutional, departmental, and program initiatives. In the next the section, we review what we know about the socialization process for graduate students with a particular focus on Black women doctoral students.

\section{Socialization: Preparing Academic Scholars and Competent Professionals}

Doctoral education functions to prepare students to become academic scholars and competent professionals. This preparation involves many facets, including knowledge of content in the chosen field and a capacity for independent scholarship (Mendoza \& Gardner, 2010). Socialization is a critical component of doctoral preparation. Socialization entails a process whereby the values, norms, knowledge, and beliefs of a group are imparted to a new member (Clark \& Corcoran, 
1986; Johnson, 2001; LaRocco \& Bruns, 2006; Reynolds, 1992). Effective socialization typically begins during graduate school and occurs prior to a new faculty member's first professional appointment (Johnsrud \& DesJarlais, 1994; McCray, 2011). Consequently, socialization as a graduate student is an important component of a new faculty member's success (Clark \& Corcoran, 1986; Johnson, 2001; Lucas \& Murry, 2007).

Often socialization activities focus solely on the discipline-based or professional knowledge and common skills required in these areas. Moreover, most socialization activities fail to address the many unstated and undocumented aspects of academic culture that new faculty identify as crucial to their professional success (Johnson, 2001; LaRocco \& Bruns, 2006; Reynolds, 1992). Research suggests that socialization of doctoral students should include discipline based knowledge received from academic integration, as well as relationship and network development received from social integration in doctoral programs (Ellis, 2001; Golde, 2000; Tinto, 1993). Underrepresented racial/ethnic doctoral students receive the academic preparation needed for socialization, but frequently lack the social interaction with faculty and others where knowledge of the "rules for success" is provided. Consequently, underrepresented racial/ethnic students are not privy to the knowledge and comprehension of the rules, both written and unwritten, that govern life in higher education and prepare new faculty for assessing and evaluating departmental culture and that can facilitate professional success (Bertrand Jones \& Osborne-Lampkin, 2013; Gonzalez et al., 2001; Turner \& Thompson, 1993).

\section{Socialization and Black women}

The small number of Black women in academia further exacerbates the issue of inadequate socialization resulting in limited Black women faculty role models. For example, only $0.6 \%$ of Black women 25 years and older held doctoral degrees in 2009 (United States Census Bureau, 2010). In the same year, only $4 \%$ of doctorates were awarded to Black women. It is not surprising then that Black women faculty comprised only $3.6 \%$ of all faculty, and $5.8 \%$ of executive/administrative positions in higher education (NCES, 2009).

The underrepresentation of Black women can be especially detrimental for Black women doctoral students. Underrepresented racial/ethnic faculty in general, and Black women in particular, face challenges in academia (Cook \& Sorcinelli, 2005; B. A. Davis, 2004; Freeman \& Taylor, 2009; Hendrix, 2007; Tuitt, 2010) that often confound the influence of inadequate socialization at the doctoral level. Black women experience isolation and alienation in departments where they are the only person of color (D. J. Davis, 2008; Jean-Marie \& Brooks, 2011; Johnsrud \& DesJarlais, 1994; McCray, 2011; Phelps, 1995), routinely have poor access to critical networks and mentoring in their respective fields of study (Bertrand Jones \& Osborne-Lampkin, 2013; Tillman, 2001; Tuitt, 2010), and, oftentimes, lack guidance while progressing through graduate programs (Border \& von Hoene, 2010; Davis-Maye, Davis, \& Bertrand Jones, 2013; Patton \& Harper, 2003). The lack of a critical mass of senior Black faculty further limits the chances for same-race or same-gender mentoring for both Black women faculty and doctoral students (Jean-Marie \& Brooks, 2011; Stanley \& Lincoln, 2005; Turner \& Gonzalez, 2015). Limited, to no, access to the formal and informal networks that exist in many departments, and more broadly disciplines, ultimately compromises these women's potential for socialization to support their professional success (Frierson, 1990; Grant \& Simmons, 2008; Patitu \& Hinton, 2003; Turner \& Thompson, 1993).

\section{Mentoring}

Mentoring is typically characterized by the relationships developed between a less experienced and an experienced professional. Mentoring may alleviate feelings of isolation and alienation in early career faculty experiences (Zellers, Howard, \& Barcic, 2008), be utilized as a tool to social- 
ize new faculty (Cawyer, Simonds, \& Davis, 2002; D. J. Davis, 2008; Ponjuan, Conley, \& Trower, 2011; Tillman, 2001), facilitate scholarly engagement (submission of publications, research, or funding opportunities) (Gregory, 2001), and contribute to the recruitment and retention of faculty of color (Johnson-Bailey \& Cervero, 2008; Stanley, 2006). The ideal mentor-mentee relationship supports doctoral students as they transition to faculty by (1) becoming familiar with institutional culture; (2) navigating office/departmental politics; (3) developing substantial relationships with senior scholars and campus partners; and (4) developing efficient, productive scholarship (Bellows, 2008; Collins, 2009; Janosik, 2009).

Opportunities for Black women to be mentored are limited (Thomas \& Hollenshead, 2001).

However, Black women are more likely to serve as mentors, particularly for students of color and other faculty of color (Griffin \& Reddick, 2011). These women use a peer approach to mentoring (Thomas \& Hollenshead, 2001) and this mentoring typically takes place outside of the department or institution (Stanley, 2006; Tillman, 2001). Ensher and Murphy (1997) found that satisfaction and contact with a mentor were higher when there were more perceived similarities between the mentor and protégé. Similarly, Jackson, Kite and Branscombe (1996, as cited in Bowman, Kite, Branscombe, \& Williams, 1999) found that Black women preferred other Black women as mentors. While the literature suggests that same race, same gender mentoring is effective, for Black women, limited Black women faculty at predominantly White institutions makes these mentoring matches limited (Tillman, 2001).

\section{Early career professional development}

Doctoral students come to academia with a range of professional experiences and qualifications which may necessitate support during the early career years and beyond (Stanley \& Watson, 2007). Professional development in doctoral education typically includes attendance or presentation at professional conferences, workshops on dissertation writing, teaching, and career track specific offerings (Gaston, 2004). Professional development may also take the shape of graduate program or human resources orientation, training or skill development workshops, classroom observations, research and teaching assistantships, individual consultation, internships, and practicum (Border \& van Hoene, 2010; Kuh \& Cuyjet, 2009; Lee, 2010; Stanley, 2010).

Through professional development, doctoral students become socialized to the many departmental, institutional, and disciplinary environments and learn about resources available to them that will assist in their academic and future professional success. In a study of doctoral students, Austin (2002) found that students perceived they were not being adequately socialized for faculty life in academia. Adequate socialization reveals the "hidden curriculum" that contributes to success in academia (Bertrand Jones \& Osborne-Lampkin, 2013; Gaston, 2004). Students needed more consistent mentoring, advising and feedback, more opportunities to talk with peers about future career related concerns, and more information about the full range of faculty life and work (Austin, 2002). Gaston (2004) suggests that mentoring and networking, and professional development experiences are part of the hidden curriculum and advises Black graduate students to engage in these activities during their doctoral programs. Moreover, the professional development of Black women doctoral students is often tied to their future productivity and ability to successfully navigate life in academia (Felder, 2010; Grant, 2012).

\section{Methods}

\section{Context of the Study}

In 2005, Sisters of the Academy (SOTA) Institute started the Research BootCamp®; an intensive, bi-annual seven-day professional development program designed to socialize Black women to academe, particularly to assist advanced doctoral students with developing their dissertation re- 
search and junior faculty in preparing peer-reviewed manuscripts. Daily seminars and workshops on research methodology, the preparation of scholarly publications, and life management within academia, among other topics specific to the participant level (i.e., doctoral student or junior scholar), are offered. Time is also allocated for individualized writing and feedback sessions with an assigned Senior Scholar Mentor, a tenured Black female in the same or a related discipline. A panel of Senior Scholar Mentors offers critique throughout the week and provides suggestions for future direction.

\section{Participants}

All participants in this study attended the Research BootCamp ${ }^{\circledR}$, the early career professional development activity sponsored by SOTA, during their doctoral studies. Attendees of the Research BootCamp ${ }^{\circledR}$ are organized by levels (i.e., doctoral student or junior scholar), which served as the basis for participant sampling for the study. A stratified purposeful sampling strategy based on attendee level was used to recruit research participants for a larger study of the Research BootCamp ${ }^{\circledR}$, in which this study was a part. The sampling strategy was used to facilitate comparisons within and across groups (Miles \& Huberman, 1994). The use of this technique particularly enhanced our ability to conduct future analyses across participant levels and program years (Bertrand Jones \& Osborne-Lampkin, 2013).

Doctoral student participants of the Research BootCamp ${ }^{\circledR}$, who are the focus of this study, were organized into two levels. Participants were either: (a) preparing dissertation research proposals (designated as Level One participants) for their approved studies; or (b) collecting or had collected data (designated as Level Two participants) for their studies. Table 1 provides details about the participants. Pseudonyms were used to maintain the anonymity and confidentiality of each participant. Each participant signed a consent form approved by the Institutional Review Board. Incentives for participation were not provided.

Table 1: Research Participants

\begin{tabular}{lllllc}
\hline Participant & \multicolumn{1}{c}{ Field of Study } & Degree & $\begin{array}{c}\text { Year of } \\
\text { RBC }\end{array}$ & Level at RBC & $\begin{array}{c}\text { Graduation } \\
\text { Year }\end{array}$ \\
\hline Katrina & Educational Leadership & Ph.D. & 2005 & Level One & 2007 \\
Adriane & Education & Ed.D. & 2007 & Level One & 2009 \\
Carol & Social Work & Ph.D. & 2007 & Level Two & 2008 \\
Tracie & Social Work & Ph.D. & 2007 & Level One & 2011 \\
Tina & Cultural Studies & Ph.D. & 2009 & Level One & 2011 \\
Anita & Public Administration & Ph.D. & 2009 & Level Two & 2011 \\
Marshay & Public Administration & Ph.D. & 2009 & Level One & 2012 \\
\hline
\end{tabular}

\section{Data Collection}

Semi-structured interviews, ranging from 60-75 minutes, were conducted with Black women who had previously participated in the Research BootCamp ${ }^{\circledR}$ as doctoral students and completed their doctorates within the last five years. In order to explore the research questions, participants responded to questions about their experience at the Research BootCamp ${ }^{\circledR}$ and how this professional development experience influenced their future career experiences. For example, participants were asked: What significant challenges have you experienced since attending the Research BootCamp? How could the Research BootCamp ${ }^{\circledR}$ experience help address those challenges? The interview protocol also included questions to identify the extent to which the Research 
BootCamp ${ }^{\circledR}$ facilitated supportive relationships to potentially enhance participants' future career experiences. For example, participants were asked: After attending the Research BootCamp ${ }^{\circledR}$ how does the social network continue to support you? A total of six interviews were taperecorded and transcribed verbatim for analysis.

While the interview transcripts were the primary data used for analysis, the research team also compiled observational field notes and reviewed program documents of the Research BootCamp ${ }^{\circledR}$ activities.

\section{Data Analysis}

We employed a multi-stage approach for coding and analyzing the data. Enumerative (i.e., collecting a number and variety of instances going in the same direction) and eliminative (i.e., testing hypotheses against alternatives and looking carefully for qualifications that bound the generality together) pattern coding was used to identify central constructs in the data (Miles, Huberman, \& Saladana, 2014; Yin, 2014). Coding was initially theory driven, guided largely by the socialization framework developed for this study, and Patricia Hill Collins' (2000) notions of Black feminism. Collins affirms the unique perspectives Black women contribute and believes this contributes to a shared understanding among Black women. Given the role of Black women in the Research BootCamp ${ }^{\circledR}$, attention to race and gender were major components in our framework.

An a priori coding framework was developed that expectedly captured race and gender in our data; a more in-depth examination of the data captured these codes and others related to the components of socialization for Black women. Descriptive codes included "professional development," "academic experiences," and "support." We began by analyzing the data categorically using these basic descriptive codes. For example, identifying "types" of "professional development activities" (e.g., professional conference activities, workshops) provided insight into the "structure" of those activities in which participants had previously engaged. By analyzing within "support," for example, we found evidence of "peer support" and "senior support." The findings were primarily organized around these codes.

At the second stage of coding and analysis, we used constant comparative analyses to further identify patterns and themes in the data (Fetterman, 1989; Merriam, 2009; Miles et al., 2014; Yin, 2014). We also used an iterative approach to capture constructs and emergent themes in the data. Data were coded and analyzed by multiple coders to minimize research bias and to ensure the quality of the conclusions (Miles et al., 2014). For example, memos were used throughout the process to record reflective thoughts as we read each interview transcript and individual responses. We all also employed strategies to test and confirm findings [e.g., triangulating across sources (i.e., participants on administrator track, participants on faculty track); checking for representativeness in findings]. NVivo 10, a qualitative data management software program, was used to organize, code, and analyze the data. The software also facilitated reliability checking between coders.

To establish dependability, we employed systematic, iterative coding approaches (Strauss \& Corbin, 1990). Member checks were also conducted with participants to confirm the accuracy and clarity of our interpretations to enhance trustworthiness. Finally, in qualitative research, the role of the researcher cannot be ignored. Patton (2002) labeled the researcher "the instrument," while Bogdan and Taylor (1975) argued "the researcher must identify and empathize with his or her subjects in order to understand them from their own frames of reference" (p. 8). As four Black women, three doctoral graduates who have transitioned into faculty positions, and one current doctoral student, we were able to identify with and understand the emerging scholars' perspectives and their experiences that were studying. Accordingly, throughout the project, Gearing's 
(2004) typology of bracketing helped us to collect our individual assumptions so as not to unintentionally impose our own experiences with those articulated by our participants.

\section{Limitations of the study}

As noted, we used semi-structured, individual interviews as a method of data collection for the study. Interview data is self-reported, relying heavily on the ability of participants to honestly recollect accounts and clearly articulate information. The use of individual interviews enabled us to obtain information that participants may perceive as personally sensitive or would not otherwise share in a larger setting. While the use of focus groups, for example, would have provided participants an opportunity to build upon and react to responses of others, participants might have been reluctant to honestly divulge information. Information surrounding academic and/or professional challenges, for example, might be perceived by participants too personal to share in group setting.

\section{Findings}

Interviews across participants suggest that almost all of the women interviewed participated in professional development activities during graduate school and prior to the Research BootCamp ${ }^{\circledR}$. Those activities included professional association conference attendance, campus workshops related to writing, and formal programs like Preparing Future Faculty, a national initiative with campus based programs that prepare graduate students for faculty life. With this exposure to a variety of professional development activities, the women identified ways that the Research BootCamp ${ }^{\circledR}$ differed from other professional development. The data suggest two distinct, salient features of the Research BootCamp ${ }^{\circledR}$ including the program's overall structure and the attention to intersectionality of identity. Findings also revealed the role the Research BootCamp ${ }^{\circledR}$ played in facilitating sustainable mentoring relationships with other Black women in the academy.

This section is divided into two sections. We begin with a discussion of features that distinguish the Research BootCamp ${ }^{\circledR}$ from other professional development activities in which participants engaged. Second, we turn to the ways in which the Research BootCamp ${ }^{\circledR}$ fostered informal and formal mentoring relationships with other Black women.

\section{Program Structure}

Participants identified the intensity of the schedule and individualized structure of the Research BootCamp ${ }^{\circledR}$ as some of the key features of the program that distinguished it from other professional development activities. Typical professional development attended by the women in our study included short-term one-day activities or, in the case of Preparing Future Faculty, longer term programs with weekly engagement. However, the Research BootCamp ${ }^{\circledR}$ is a week-long program in which attendees arrive on Sunday for orientation with program activities concluding the following weekend. Participants' days throughout the program involve intentionally scaffolded activities, including allotted times for workshops, writing, and meetings with their assigned Senior Scholar Mentors. On average, attendees spend between 10-12 hours each day engaged in planned Research BootCamp ${ }^{\circledR}$ activities. In our interviews, women spoke of returning to their lodging at the end of the official day of activities and continuing to work for another four to six hours in the company of other participants, many of whom shared living space.

Participants described the intense, tailored structure of the program, and expectations set from the beginning of the program as motivation for their active engagement throughout and even after the Research BootCamp ${ }^{\circledR}$ ended. They used words like "transformative," "dynamic," and "intense" to describe their experience. Carol noted the challenge and encouragement she experienced: 
It was as the name implies. It was a BootCamp it was challenging, it was very intense, but I appreciate the experience. I can almost equate it to if someone is almost in the military. When they go through the BootCamp it's intense, but the sole purpose is to prepare that individual for challenges they'll face on down the road. It was challenging, but it was encouraging and the challenge helped me develop more independent skills as it relates to working on my dissertation.

Participants have access to and engagement of session facilitators throughout the week-long program. Most of the Research BootCamp ${ }^{\circledR}$ workshop presenters remain throughout the entire week of the program. As a result, participants have access to these women long after their session ends. Katrina, a participant of the first Research BootCamp ${ }^{\circledR}$, mentioned the opportunity to follow-up with workshop presenters, or other participants, after sessions unlike other professional development experiences:

Most of those outside professional development opportunities are normally just a one day workshop or seminar. So if you leave that seminar and think of something you really wanted to ask the person you're not able to because the workshop is over. At the BootCamp ${ }^{\circledR}$ you came in on a Sunday and you were there until the next Sunday and you had the opportunity to write down those questions and your questions were answered before you left. So it was more of a turnaround effect where you didn't have to wait or call someone. You were there and you had that contact where if you left the campus, fine, and you went for dinner there was a possibility that those same people would be eating dinner with you so you could get your questions answered.

In the application process, participants were asked to identify "the most pressing issues" for them. The program was also structured to meet the individual needs of participants based on the stage in which they were in their programs or careers. For example, Anita described how the program provided the foundation for organizing her dissertation work and attributed the short time that elapsed between her dissertation proposal defense and subsequent graduation. She explained:

I defended my dissertation proposal in October of 2010 and I graduated in May of 2011. So, I was able to do everything in a very small frame of time and that's largely because of what I was able to do the foundation I was able to lay in the BootCamp. The BootCamp really helped me to kind of get through everything that followed once I left, so the drafting the mini draft of the proposal getting that done, going through the presentation having had that experience at the BootCamp really helped me, defending my dissertation proposal, and then going through the dissertation process.

Marshay, who participated in two Research BootCamps ${ }^{\circledR}$, identified the personal attention she received as holistic, explaining:

It's very centered, you get a holistic experience and you're not limited to academics, you get the sisterhood, you get the nurturing, you get the ... I don't want to say emotional, but yeah you do get the emotional support you need that lacks in professional programs of this nature ... you get the personal attention as well.

\section{Intersectionality of Identity}

As previously noted, the Research BootCamp ${ }^{\circledR}$ is sponsored by SOTA Institute. The organization's mission is to provide a network for Black women in higher education. The SOTA Leadership Team was responsible for program implementation. As a result, the Senior Scholar Mentors, workshop presenters, and most volunteers at the Research BootCamp® identifying as Black women was not an accident. Program materials reflected a purposeful emphasis on the intersection of race and gender. Research BootCamp ${ }^{\circledR}$ participants in another study identified the inten- 
tional attention to race and gender as unique to the Research BootCamp® (Bertrand Jones \& Osborne-Lampkin, 2013). Similarly, participants in this study described how those attending and leading the program being Black women was a unique feature of the professional development experience and helped to create a "safe and supportive environment." Tina explained:

I find going through the process that while I love my colleagues of all stripes that there are some very specific experiences that women of color face in the doctoral process. I wanted to be in an environment where I could speak about that openly without judgment or ridicule and feel a sense of camaraderie, understanding and also get some support and some real strategies about navigating those strategies from people who knew them well.

Authenticity was an important feature of the all Black woman environment. Tina relayed a story of her previous experience in what she called "woman-centered places" and the disappointment she felt when those environments failed to meet her expectations of safety.

One of the things that make it [the RBC] so special is that I have been in other places in my life that were supposed to be woman-friendly or woman-centered places and that were supposed to be full of encouragement and support and that has not always been the case. When it hasn't been the case I find that I felt emotionally hurt by that. I was really hoping that at the BootCamp I would be there with women who were really committed, not there for their own success, but who really were interested in me and what I was trying to do. Who really wanted to help me and were not just saying they were going to be my sisters, but they really were my sisters and that's what really happened.

While Tina's comments highlight the importance of attendees' emotional safety, other attendees identified a level of care they experienced from the other Black women at the Research BootCamp ${ }^{\circledR}$, further illuminating the role race and gender played in creating a unique professional development experience. Anita noted:

Faculty who were there really care about the women at the BootCamp and they really care about them finishing and ending up with a quality project. It's so evident and it's nothing that's necessarily verbalized in a very specific way but everything that's done the conversations that are had you could really tell that there is a genuine interest in getting you to where you ultimately needed to be as a doctoral student and I think that is where by far the one thing that sets the BootCamp apart from anything else. There is a group of women there that want you to be successful, that care about your success, that care about you finishing. You don't even know them, but you come in knowing from that first dinner you get the sense there's this understanding that they are there to get you where you need to go and that doesn't always mean to tell you what you want to hear. But there is that genuine interest, there is that genuine care that's there.

Similarly, Tracie depicted a connection amongst the participants inspired by race and gender and the added pursuit of a doctoral degree or a career in academia. She stated:

You have a sense of camaraderie with women of color from different walks, but yet striving for the same goals and having someone to say, 'I've done this', or that they have gone through the fire before you. So it gives you a sense of comfort knowing that it is attainable and achievable irrespective of what you've seen already or other experiences you've had.

Other participant responses were aligned with those discussed above.

\section{Sustainable Mentoring Relationships}

The second research question was specifically designed to understand the extent to which the Research BootCamp ${ }^{\circledR}$ facilitated sustaining, supportive relationships and networks. Mentoring is 
one of the hallmarks of the Research BootCamp ${ }^{\circledR}$ as reflected in program materials. Each Senior Scholar Mentor has both doctoral students and junior scholars assigned to their small group for mentoring. The program also offers numerous opportunities for networking with participants at all levels throughout the week. All participants identified the mentoring they received at the Research BootCamp ${ }^{\circledR}$ as another key feature of the program, acknowledging the mentoring from Senior Scholar Mentors, as well as peers, and other members of Sisters of the Academy who attend the Research BootCamp®. While we expected that opportunities to develop relationships with peers and senior faculty members would be identified as a key feature, the extent to which the Research BootCamp ${ }^{\circledR}$ facilitated relationships that extended beyond the professional development opportunity was notable.

Marshay identified the encouragement provided by the mentoring relationships as an essential component of her experience. She said: "Definitely the mentorship, the access to the Senior Scholars, as well as other scholars, my peers, for encouragement and things like that." Anita noted, "the potential to develop all of these great relationships stemming from that one week BootCamp."

In the program participants are matched with Senior Scholar Mentors from their academic disciplines or with individuals whose research interests are closely aligned. Tracie discussed the benefits of the relationships she developed with scholars from her field, including opportunities for scholarly collaboration.

Through BootCamp I was able to connect and network with some senior scholars and junior scholars and through that relationship I have two publications. Actually maybe three, but definitely two publications and I am making progress. And I think a lot of it has to do with having the exposure from BootCamp and being introduced to other individuals like me that were doing the same type of work.

Tina, however, expressed her initial concern about being matched with a scholar outside of her area. She explained:

At first I was nervous saying to myself maybe this is something that's discipline specific and I won't be able to get the kind of help that I need. But because the SOTA model is so open and is so flexible and also so thoughtful, I feel that in matching me with the kind of mentoring support that I got I didn't feel at any point that there was a problem around what discipline I was in, what I wasn't studying.

While we expected that opportunities to develop relationships with peers and senior faculty members would be identified as a key feature, the extent to which the Research BootCamp ${ }^{\circledR}$ facilitated relationships that extended beyond the professional development opportunity was notable. For example, the women in our study not only described the level of engagement and the specific roles the mentors played during the Research BootCamp, ${ }^{\circledR}$ but also described subsequent interactions after the event. According to participants, the Senior Scholar Mentors at the Research BootCamp ${ }^{\circledR}$ exhibited a higher level of engagement than experienced in other professional development activities, and even some home institutions. Anita said:

It's very rare to have an opportunity to where you have senior faculty members sit down with you one on one. It's very basic, but it's so needed. This is what you do here, this is what you do there, this is what you do in step three. I mean it was crucial to getting me finished.

Participants discussed the continued engagement with peers and Senior Scholar Mentors after the Research BootCamp ${ }^{\circledR}$. Many reported using email, phone, and social media (e.g., Facebook) to maintain communication. Katrina described the role her Senior Scholar Mentor played in reviewing her dissertation after the program. 
At the BootCamp I met a lot of people so it was an opportunity for networking and having an opportunity to get a mentor, [Senior Scholar Mentor] was my mentor. She worked with me at the BootCamp, after I left the BootCamp ... she critiqued my dissertation, she gave me feedback, so she followed me through my process and after that also with other activities I was involved in. I could call and get information on things that I didn't understand.

Anita reflected on her relationship post-BootCamp, with a Senior Scholar Mentor who lived in her area:

You have your senior scholar that you are assigned to and then you find that you develop relationships with other people and I ended up developing a relationship with [another Senior Scholar Mentor] which was nice. She's close to where I am so I have been able to see her since leaving the BootCamp and she gave me some qualitative articles that were very beneficial for me in finishing. So it was nice to be able to have that mentoring during that week and then also have the opportunity of having it extend beyond that week.

Similarly, Katrina noted:

I still have an opportunity to talk with people that I met at the BootCamp. If I need to know anything or I need any help we communicate via e-mail, sometimes we talk on the phone and we do Facebook so it's really a never ending process as far as the people you meet at the BootCamp, you may not communicate with all of the ones, but I ended up still continuing to talk to some of them.

Adriane articulated the personal and professional functions the network she developed at the Research BootCamp® served:

I have people that I can call and say I'm working on this can you help me? But then I can also use it for several aspects of my life, not just professionally but personally and spiritually. I have one of the people that I met at the BootCamp that we are of the same faith and we can continue to converse back and forth about a number of issues, but also about our faith and about how to kind of be strong in this time of whatever time we're in. I have several layers and several levels of people that I can talk to about a lot of different things so I know if I need to talk about a specific topic I know I can talk to these five people that I met during the BootCamp. So that's how my network continues to work for me because I'm still in contact with people and I'm able to continue to integrate them into my space and my life and what I'm doing now and use them as a tool.

\section{Conclusion}

The benefits of mentoring and contribution of early career professional development for doctoral students related to the rigors of the academy cannot be denied. As the responsibilities of new faculty continue to shift, the training approaches, foundational theories, and best practices associated with the profession, should be altered in order to paint a more accurate portrait of what professional life in academia entails (Ouellett, 2010). The complexity of this work is only magnified by the recognition of the intersectionality of identity that further contextualizes Black women's lives in academia. Consequently, there are nuances to academia for Black women that are not often articulated in traditional socialization processes. Traditional mentoring and professional development typically fail to address the intersectionality of Black women's experiences (Bertrand Jones \& Osborne-Lampkin, 2013).

The Research BootCamp ${ }^{\circledR}$ is a formal structure that serves as a mechanism for tailored support in an environment that not only acknowledges, but embraces, the intersections of race and gender. The Research BootCamp ${ }^{\circledR}$ also facilitates formal mentoring relationships to support the devel- 
opment of Black women who aspire to serve in the academy and potentially enhance the shortterm and long-term success. As such, the tenets of the Research BootCamp ${ }^{\circledR}$ model can be used to serve as a framework for other institutional and departmental models to enhance the socialization process for Black women, and potentially students of color more broadly.

For example, while the findings regarding the value of developing mentoring relationships was not surprising, the Research BootCamp ${ }^{\circledR}$ 's ability to facilitate sustaining relationship is aligned with other research that has found that such networks are especially important for Black women's socialization (Denton, 1990). These networks provide social support, create outlets for professional development, build research capacity, and influence socialization to the academy. This support increases the likelihood of exposure to collaborative research opportunities, and the development of social relationships with women who not only share a common profession, but can also relate to challenges these early career faculty face related to race and gender. Given the small numbers of these women in institutions, Black women often look outside of their home institution for mentors (Bertrand Jones, Wilder, \& Osborne-Lampkin, 2015). This fact further underscores the need for formal structures available at institutions and within departments that address these needs for Black women in particular, and students of color broadly.

Findings from our study provide a deeper understanding of the participants' experiences at the Research BootCamp ${ }^{\circledR}$ and aspects of the professional development program that were most salient to these Black women. While the key findings that highlight the Research BootCamp ${ }^{\circledR}$ 's structure and attention to race and gender provide credence for the uniqueness of the model of the professional development program, findings from this study can also inform professional development initiatives being implemented within institutions, departments, and programs, alike.

Research, for example, suggests that the academy could improve upon growth and development efforts for Black women specifically, and underrepresented faculty broadly, by acknowledging the pressures unique to their experience, validating their contributions to the academy, and increasing their access to role models and networks (Tuitt, 2010). Consistent with findings from prior studies, our findings on the significance of the intersection of race and gender in professional development activities and in mentoring relationships beckons the call for institutional and departmental administrators to critically reflect on and evaluate existing programs and policies to determine missing elements that further support the development of underrepresented students, particularly students of color and women.

As administrators recognize the perpetual inequity that underrepresented students and faculty experience within the academy, they can potentially improve their opportunities for recruitment, socialization, and advancement (Tuitt, 2010). Comprehension of pertinent issues can also assist institutions as they assess traditional methods of supporting emerging scholar development (students and junior faculty) and position them to design innovative programs that effectively address the complex needs of underrepresented groups. As institutions move towards, as Young and Brooks (2008) put it, "a coherent, integrated component of a strategic plan" to support students and junior faculty of color, formalized structures and supporting mechanisms are key. For example, Johnson and Snider (2015) assert that formalized programs, specifically mentoring programs, at the institutional and departmental levels to support graduate students and junior faculty, particularly those of color, "spread the responsibility and send a message from the top-down that the university values mentoring and acknowledges the tremendous benefits mentoring provides" (p.13).

Institutionalized programs targeted towards underrepresented racial/ethnic doctoral students can prove critical in doctoral student success and transition into the academy. Looking to professional development opportunities like the Research BootCamp ${ }^{\circledR}$ can potentially move institutions, de- 
partments, and programs closer to a more systematic approach to socializing graduate students and faculty of color, particularly Black women.

\section{References}

Austin, A. E. (2002). Preparing the next generation of faculty: Graduate school as socialization to the academic career. The Journal of Higher Education, 73(1), 94-122.

Bellows, L. (2008). Graduate student professional development: Defining the field. Studies in Graduate and Professional Student Development, 11, 2-19.

Bertrand Jones, T., \& Osborne-Lampkin, L. (2013). Early career professional development: Enhancing Black female faculty success. Negro Educational Review 64(1-4), 59-75.

Bertrand Jones, T., Wilder, J. A., \& Osborne-Lampkin, L. (2015). Beyond sisterhood: Using shared identities to build peer mentor networks and secure social capital in the academy. In B. L. H. Marina (Ed.), Mentoring away the glass ceiling in academia: A cultured critique (pp. 143-159). Lanham, MD: Lexington Books.

Bogdan, R., \& Taylor, S. J. (1975). Introduction to qualitative research methods: A phenomenological approach to the social sciences. New York: Wiley.

Border, L. L. B., \& von Hoene, L. M. (2010). Graduate and professional student development programs. In K. J. Gillespie, D. L. Robertson, \& Associates (Eds.), A guide to faculty development $\left(2^{\text {nd }}\right.$ ed., pp. 327345). San Francisco, CA: Jossey-Bass.

Bowman, S., Kite, M. E., Branscombe, N. R., \& Williams, S. In A. J. Murrell, F. J. Crosby, \& R. J. Ely (Eds.), Mentoring dilemmas: Developmental relationships within multicultural organizations (pp.1942). Mahwah, NJ: Lawrence Erlbaum Associates.

Cawyer, C. S., Simonds, C., \& Davis, S. (2002). Mentoring to facilitate socialization: The case of the new faculty member. International Journal of Qualitative Studies in Education, 15(2), 225-242.

Clark, S. M., \& Corcoran, M. (1986). Perspectives of the professional socialization of women faculty: A case of accumulative disadvantage? The Journal of Higher Education, 57(1), 20-43.

Collins, D. (2009). The socialization process for new professionals. In A. Tull, J. B. Hirt, \& S. Saunders (Eds.), Becoming socialized in student affairs administration: A guide for new professionals and their supervisors (pp. 3-27). Sterling, VA: Stylus.

Collins, P.H. (2000). Black feminist thought: Knowledge, consciousness, and the politics of empowerment. New York: Routledge.

Cook, C. E., \& Sorcinelli, M. D. (2005). Building multiculturalism into teaching development programs. In M. L. Ouellett (Ed.), Teaching inclusively: Resources for course, department, and institutional change in higher education (pp. 3-20). Stillwater, OK: New Forums.

Davis, B. A. (2004). The slippery slope of student evaluations for Black women faculty. In C. Y. Battle \& C. M. Doswell (Eds.), Building bridges for women of color in higher education: A practical guide for success. Lanham, MD: University Press of America.

Davis, D. J. (2008). Mentorship and the socialization of underrepresented minorities into the professoriate: Examining varied influences. Mentoring \& Tutoring: Partnership in Learning, 16(3), 278-293.

Davis, D. J., Reynolds, R., \& Bertrand Jones, T. (2011). Promoting the inclusion of tenure earning Black women in academe: Lessons for leaders in education. Florida Journal of Educational Administration and Policy, 5(1), 28-41.

Davis-Maye, D., Davis, D. J., \& Bertrand Jones, T. (2013). Who's got next: SOTA's KEMET Academy as a model to improve the community college to $\mathrm{PhD}$ pipeline. The Journal of Negro Education, 82(3), 243-254. 
Denton, T. C. (1990). Bonding and supportive relationships among black professional women: Rituals of restoration. Journal of Organizational Behavior, 11(6), 447-457.

Ellis, E. M. (2001). The impact of race and gender on graduate school socialization, satisfaction with doctoral study, and commitment to degree completion. Western Journal of Black Studies, 25(1), 30-46.

Ensher, E. A., \& Murphy, S. E. (1997). Effects of race, gender, perceived similarity, and contact on mentor relationships. Journal of Vocational Behavior, 50(3), 460-481.

Felder, P. (2010). On doctoral student development: Exploring faculty mentoring in the shaping of African American doctoral student success. The Qualitative Report, 15(3), 455-474.

Fetterman, D. M. (1989). Ethnography: Step by step (Applied Social Research Methods Series, No. 17). Newbury Park, CA: Sage.

Frierson, H. T. (1990). The situation of Black educational researchers: Continuation of a crisis. Educational Researcher, 19(2), 12-17.

Freeman, J. P., \& Taylor, C. (2009). Characteristics and socialization. In A. Tull, J. B. Hirt, \& S. Saunders (Eds.), Becoming socialized in student affairs administration: A guide for new professionals and their supervisors (pp. 67-85). Sterling, VA: Stylus.

Gaston, J. (2004). Preparing for the professoriate. In D. Cleveland (Ed.), A long way to go: conversations about race by African American faculty and graduate students (pp. 32-40). New York: Peter Lang Publishing.

Gearing, R. E. (2004). Bracketing in research: A typology. Qualitative Health Research, 14(10), 14291452.

Golde, C. M. (2000). Should I stay or should I go? Student descriptions of the doctoral attrition process. Review of Higher Education, 23(2), 199-227.

Golde, C. (2010). Entering different worlds: Socialization into disciplinary communities. In S. K. Gardner \& P. Mendoza (Eds.), On becoming a scholar: Socialization and development in doctoral education (pp. 79-95). Sterling, VA: Stylus Publishing, LLC.

Gonzalez, K. P., Marin, P., Perez, L. X., Figueroa, M. A., Moreno, J. F., \& Navia, C. N. (2001). Understanding the nature and context of Latina/o doctoral student experiences. Journal of College Student Development, 42(6), 563-80.

Grant, C. M. (2012). Advancing our legacy: A black feminist perspective on the significance of mentoring for African-American women in educational leadership. International Journal of Qualitative Studies in Education, 25(1), 101-117.

Grant, C. M., \& Simmons, J. C. (2008). Narratives on experiences of African-American women in the academy: Conceptualizing effective mentoring relationships of doctoral student and faculty. International Journal of Qualitative Studies in Education, 21(5), 501-517.

Gregory, S. T. (2001). Black faculty females in the academy: History, status, and future. The Journal of Negro Education, 70(3), 124-138.

Griffin K. A., \& Reddick, R. J. (2011). Surveillance and sacrifice: Gender differences in the mentoring patterns of Black professors at predominantly White research universities. American Educational Research Journal. doi:10.3102/0002831211405025

Hendrix, K. G. (2007). Neither white nor male: Female faculty of color. (New Directions for Teaching and Learning Vol. 110). San Francisco, CA: Jossey-Bass.

Janosik, S. M. (2009). Professional associations and socialization. In A. Tull, J. B. Hirt, \& S. Saunders (Eds.), Becoming socialized in student affairs administration: A guide for new professionals and their supervisors (pp. 194-214). Sterling, VA: Stylus.

Jean-Marie, G., \& Brooks, J. S. (2011). Mentoring and supportive networks for women of color in academe. In G. Jean-Marie, \& B. Lloyd-Jones (Eds.) Women of color in higher education: Contemporary 
perspectives and new directions, Volume 9, Diversity in Higher Education Series (pp. 91-108). Bingley, UK: Emerald.

Johnson, B. J. (2001). Faculty socialization: Lessons learned from urban Black colleges. Urban Education, 36(5), 630-647. doi: 10.1177/0042085901365007

Johnson, J., \& Snider, J. (2015). Phoward progress: Mentoring ahead through mentorship in the academy. In B. L. H. Marina (Ed.). Mentoring away the glass ceiling in academia: A cultural critique (pp. 3-16). Lanham, MD: Lexington Books.

Johnson-Bailey, J., \& Cervero, R.M. (2008). Different worlds and divergent paths: Academic careers defined by race and gender. Harvard Educational Review, 78(2), 311-332

Johnsrud, L. K., \& DesJarlais, C.D. (1994). Barriers to tenure for women and minorities. The Review of Higher Education, 17(4), 335-353.

Kuh, L., \& Cuyjet, M.J. (2009). Graduate preparation programs: The first step in socialization. In A. Tull, J. B. Hirt, \& S. Saunders (Eds.), Becoming socialized in student affairs administration: A guide for new professionals and their supervisors (pp. 89-108). Sterling, VA: Stylus.

LaRocco, D. J., \& Bruns, D. A. (2006). Practitioner to professor: An examination of second career academics' entry into academia. Education, 126(4), 626-639.

Lee, V. S. (2010). Program types and prototypes. In K. J. Gillespie, D. L. Robertson, \& Associates (Eds.), A guide to faculty development ( $2^{\text {nd }}$ ed., pp. 21-33). San Francisco, CA: Jossey-Bass.

Lucas ,C. J., \& Murry, J. W. (2007). New faculty: A practical guide for academic beginners (2 ${ }^{\text {nd }}$ ed.). New York: Palgrave Macmillan.

McCray, E. D. (2011). Woman(ist)s' work: The experiences of Black women scholars in education at predominantly White institutions. In G. Jean-Marie \& B. Lloyd-Jones (Eds.), Women of color in higher education: Turbulent past, promising future, Volume 9, Diversity in Higher Education Series (pp. 99125). Bingley, UK: Emerald.

Mendoza, P., \& Gardner, S. K. (2010). The Ph.D. in the United States. In S. K. Gardner \& P. Mendoza (Eds.) On becoming a scholar: Socialization and development in doctoral education (pp.11-26). Sterling, VA: Stylus.

Merriam, S. (2009). Qualitative research: A guide to design and implementation. San Francisco: JosseyBass.

Miles, M. B., \& Huberman, A. M. (1994). Qualitative data analysis: An expanded sourcebook (2nd ed.). Newbury Park, CA: Sage.

Miles, M. B., Huberman, A. M., \& Saldaña, J. (2013). Qualitative data analysis: A methods sourcebook ( $3^{\text {rd }}$ ed.). Newbury Park, CA: Sage.

National Center for Education Statistics (NCES) (2009). Digest of education statistics: 2009. Retrieved from http://nces.ed.gov/programs/digest/d09/

Ouellett, M. L. (2010). Overview of faculty development: History and choices. In K. J. Gillespie, D. L. Robertson, \& Associates (Eds.), A guide to faculty development ( ${ }^{\text {nd }}$ ed.). San Francisco, CA: JosseyBass.

Patitu C. L., \& Hinton, K. G. (2003). The experiences of African American female faculty and administrators in higher education: Has anything changed? New Directions for Student Services, 104, 79-93.

Patton, M. Q. (2002). Qualitative research and evaluation methods ( $3^{\text {rd }}$ ed.). Thousand Oaks, CA: Sage.

Patton, L. D., \& Harper, S. R. (2003). Mentoring relationships among African American women in graduate and professional schools. New Directions for Student Services, 2003(104), 67-78.

Phelps, R. E. (1995). What's in a number: Implications for African American female faculty at predominantly White colleges and universities. Innovative Higher Education, 19(4), 255-268. 
Ponjuan, L., Conley, V. M., \& Trower, C. (2011). Career stage differences in pre-tenure track faculty perceptions of professional and personal relationships with colleagues. The Journal of Higher Education 82(3), 319-346.

Reynolds, A. (1992). Charting changes in junior faculty: Relationships among socialization, acculturation, and gender. The Journal of Higher Education, 63(6), 637-652.

Stanley, C. A. (2006). Coloring the academic landscape: Faculty of color breaking the silence in predominantly White colleges and universities. American Educational Research Journal, 43(4), 701-736.

Stanley, C. A. (2010). Conceptualizing, designing, and implementing multicultural faculty development activities. In K. J. Gillespie, D.L. Robertson, \& Associates (Eds.), A guide to faculty development ( $2^{\text {nd }}$ ed., pp. 203-224). San Francisco, CA: Jossey-Bass.

Stanley, C. A. \& Lincoln, Y. S. (2005). Cross-race faculty mentoring. Change, 37(2), 44-50.

Stanley, C. A., \& Watson, K. L. (2007). Meeting the professional development needs of new faculty: A three-year evaluation study of a new faculty orientation program. Journal of Faculty Development, 21(3), 149-160.

Strauss, A., \& Corbin, J. M. (1990). Basics of qualitative research: Grounded theory procedures and techniques. Thousand Oaks, CA: Sage.

Thomas, C. D., \& Hollenshead, C. (2001). Resisting from the margins: The coping strategies of Black females and other females of color faculty members at a research university. Journal of Negro Education, $70(3)$, p. 166-175.

Tillman, L. C. (2001). Mentoring African American faculty in predominantly White institutions. Research in Higher Education, 42(3), 295-325.

Tinto, V. (1993). Leaving college: Rethinking the causes and cures of student attrition (2nd ed.). Chicago: The University of Chicago Press.

Tuitt, F. (2010). Working with underrepresented faculty. In K. J. Gillespie, D. L. Robertson, \& Associates (Eds.), A guide to faculty development ( $2^{\text {nd }}$ ed., pp. 225-242). San Francisco, CA: Jossey-Bass.

Turner, C.S.V., \& Gonzalez, J.C. (2015).Modeling mentoring across race/ethnicity and gender: Practices to cultivate the next generation of diverse faculty. Sterling, VA: Stylus.

Turner, C. S. V., \& Thompson, J.R. (1993). Socializing women doctoral students: Minority and majority experiences. Review of Higher Education, 16, 355-370.

Turner, C. S. V., Wood, J. L., Montoya, Y. J., Essien-Wood, I. R., Neal, R., Escontrías, G., \& Coe, A. (2012). Advancing the next generation of higher education scholars: An examination of one doctoral classroom. International Journal of Teaching and Learning in Higher Education, 24(1), 103-112.

United States Census Bureau (2010). Current population survey: 2009 annual social and economic supplement. Retrieved from http://www.census.gov/apsd/techdoc/cps/cpsmar09.pdf

Winkle-Wagner, R., Johnson, S. D., Morelon-Quainoo, C., \& Santiague, L. (2010). A sense of belonging: Socialization factors that influence the transitions of students of color into advanced-degree programs. In S. K. Gardner \& P. Mendoza (Eds.), On becoming a scholar: Socialization and development in doctoral education (pp. 179-199). Sterling, VA: Stylus Publishing, LLC.

Yin, R. Y. (2014). Case study research: Design and methods, (5 $5^{\text {th }}$ edition). Los Angeles: Sage.

Young, M.D., \& Brooks, J.S. (2008). Supporting graduate students of color in educational administration preparation programs: Faculty perspectives on best practices, possibilities, and problems. Educational Administration Quarterly, 44(3), 391- 423. doi: 10.1177/0013161X08315270.

Zellers, D. F., Howard, V. M., \& Barcic, M. A. (2008). Faculty mentoring programs: Re-envisioning rather than reinventing the wheel. Review of Educational Research, 78(3), 552-588. 


\section{Biographies}

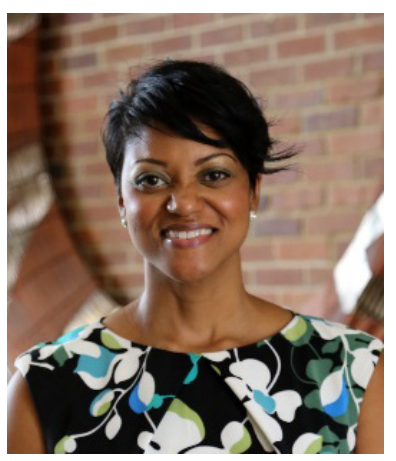

Tamara Bertrand Jones is an Assistant Professor of Higher Education and Senior Research Associate for the Center for Postsecondary Success at Florida State University. Her research examines the sociocultural influences on socialization during graduate education and the professional experiences of underrepresented populations, particularly Black women, in academia. Her previous work as an administrator and program evaluator also influence her other research interests in culturally responsive assessment and evaluation.

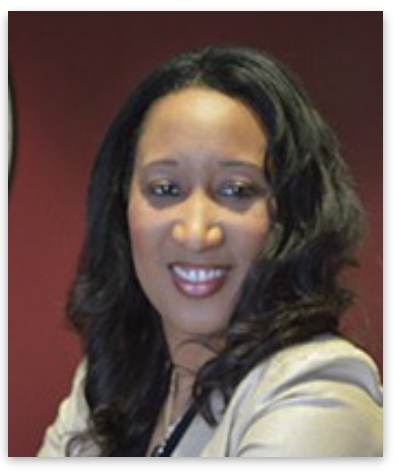

La'Tara Osborne-Lampkin is an Associate in Research at Florida State University. Her research focuses on accountability policies and reform efforts designed to increase educational outcomes for underrepresented student populations in K-12 and post-secondary settings, with a recent focus on principal-related reform efforts. As a policy and research scholar, she is particularly interested in conducting and advancing research on policies and practices designed to enhance the recruitment, retention, and outcomes of minority faculty and graduate students in higher education institutions.

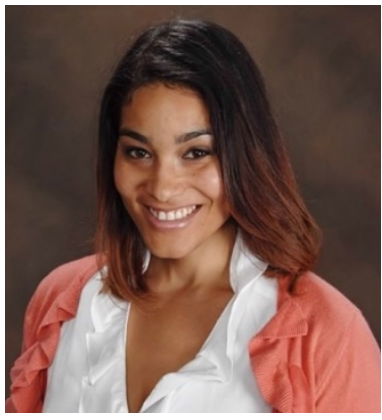

Shawna M. Patterson is a PhD candidate in Higher Education a Florida State University. Her research focuses on student of color identity development, critical theory, and social justice in higher education. Shawna has nine years of student affairs administration experience within the functional areas of residence life and multicultural services in the Big 10 and ACC. She currently serves as a Dean in College Houses and Academic Services, as well as a Pre-Major Advisor for the College of Arts and Sciences at the University of Pennsylvania.

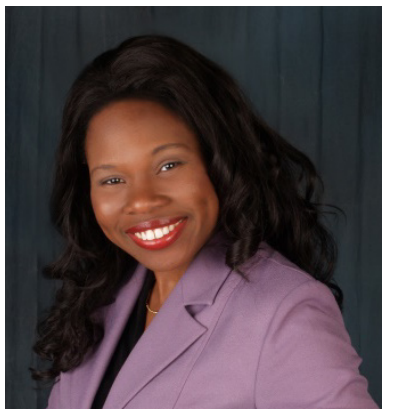

Dannielle Joy Davis is an Associate Professor at St Louis University. A graduate of the University of Illinois at Urbana-Champaign, she has studied and conducted research in Ghana, South Africa, Egypt, Germany, the Netherlands, and Belgium. Her interdisciplinary research examines the experiences of marginalized groups in educational settings, the role of organizational policy and practice in the promotion or inhibition of egalitarian academic and occupational outcomes, and spirituality in the workplace. She has published over 35 refereed journal articles, book chapters, academic commentaries, volumes, and reviews. Davis has co-edited the books Black Women in Leadership (Peter Lang Publishing) and Social Justice Issues and Racism in the College Classroom (Emerald Publishing). Dr Davis has served as an Associate Editor for Learning for Democracy: An International Journal of Thought and Practice which is sponsored by the AERA SIG, Democratic Citizenship in Education. 